\title{
Implementation Of School Accreditation Policy at State Elementary School in Medan Area Districts
}

\author{
Windari $^{1)}$ \\ Elemantary School's Teacher Medan \\ Area North Sumatra, Indonesia \\ windari.sofyan@yahoo.co.id
}

\author{
Darwin $^{2)}$ \\ Lecturer at State University of \\ Medan,North Sumatra, Indonesia
}

\author{
Sukarman Purba ${ }^{3)}$ \\ Lecturer at State University of \\ Medan,North Sumatra, Indonesia
}

\begin{abstract}
The aim of this study; a) finding out the description of the communication / dissemination of the State Primary Schoo accreditation policy in Medan Area District; b) knowing the form of Human Resources (HR) in the implementation of State Primary School accreditation policies in Medan Area District; c) knowing the bureaucratic support for the State Primary School accreditation policy in the Medan Region; and d) finding out how the policy disposition to reach the State Primary School in Medan Area was studied using the theory of policy implementation according to George C. Edward III theory. The method of this study is qualitative research methods, Data analysis techniques used taxonomic analysis with the analysis process. The primary data source of this study were the Head of Unit Tehcnic Performing Regency Education and Culture Office in Medan District, the School Accreditation Implementation Team, the School's Principal, and several Primary School teachers in the Medan Area.. The research location is in public elementary schools located in Medan Area, Medan North Sumatra, Indonesia. The results of this study indicate that: a) communication form of policies acreditation of State Primary Schools in Medan Area District is meeting oriented, b) Availability of Human Resources in the implementation of Primary School accreditation in Medan Area are, c) Disposition form in this study are Recruitment, Discipline, Performance and Incentives, and d) The form of bureaucratic support for the implementation of the accreditation policy at the Medan Area State Elementary School is the existence of fragmentation and SOPs
\end{abstract}

Keywords - school's acreditation; communication; human resources; bureaucratic; disposition

\section{INTRODUCTION}

The background of the school accreditation policy in Indonesia is that every citizen has the right to quality education. To be able to carry out quality education, each education unit / program must meet or exceed the standards carried out through accreditation activities on the feasibility of each educational unit / program.

In order to improve the quality of national education in stages, planned and measured in accordance with the mandate of Law Number 20 of 2003 concerning the National Education System, Chapter XVI Part Two Article 60 concerning Accreditation, the Government conducts accreditation to assess the feasibility of programs and / or education units. In this case, the Government has established a National School / Madrasah Accreditation Agency (BAN-S / M) with Minister of National Education Regulation No. 29 of 2005.
The success of the policy of implementing accreditation for educational/school institutions cannot be separated from; 1) government socialization to the school, 2) support for accreditation of implementing Natural Resources (HR), 3) applicable bureaucracy, 4) disposition of activities, and 5) how the application of accreditation policies can be used in subsequent decision making.

The [1] author mentions that socialization is a process to implement ideas, and processes or a series of new activities with the hope that others can accept and make adjustments and participation.

Furthermore, according to [2] because accreditation is public policy, policy socialization is a process by which humans learn through means, values and adjust actions to other communities and cultures by requiring three stages of the socialization process, namely: a) the preparation stage, b) the imitation stage, c) the stage is ready to act, and d) the stage of acceptance of collective norms.

Why is this research so useful? The research relevant to this research is the first research on the implementation of accreditation and its relationship to improve the quality of education (case study at MTs Serpong) by Ida Saidah in 2006. However, this study only examined the positive relationship between the implementation of school accreditation and the quality of education

The second study entitled The Influence of School Accreditation, Learning Management, and the School Committee on the Quality of Education in School-Based Management Pilot Schools (Case Study at Public Junior School 2, Public Junior School 3, Domenico Savio Middle School Semarang) by Sutikno in 2004. This study also only focused on procedures for managing learning, and the school committee's response to the quality of the SBM Pilot School Semarang in Semarang.

The third study was the Influence of School Accreditation on Education Quality Improvement in Bandung Middle School by Anita Solihatiningsih in 2006. The purpose of this study was only to see the effect of accreditation on improving the quality of high schools throughout the city of Bandung.

Relevant to the interests of the accreditation policy, this is based on the survey conducted in January 2018 from the Education Office at the Technical Implementation Unit in 
Medan Area Sub district with 23 Primary Schools with A (13.04\%), B (82.60\%), and C (4.36\%).

From several developing policy implementation theories, relevant policy theory as a tool for policy analysis on education is the theory put forward by George C. Edward III for reasons, as follows:

First is observed, this criterion indicates that each indicator used as a reference for the development of an assessment item must be observable for its substance and existence.

Second is Measured, this criterion shows that each indicator can be measured and shown.

Practically, this criterion indicates that each indicator item can be derived which will be used as a tool to assess school performance.

Relevant, this criterion shows that every indicator developed must be relevant to the expectations of stakeholders in the school.

Representative, this criterion shows that each indicator developed must represent certain aspects of the school quality component.

Based on the description above, the basis of this study focused on the implementation of the State Primary School accreditation policy by BAS in the Medan Area Subdistrict by using policy implementation theory according to George C. Edward III.

\section{LITERATURE RIVIEW}

\section{A. Understanding Public Policy}

According to [3] author said that public policy is whatever the government's choice to do or not to do. While according to the [4] athour policies as "behavioral consistency and repetitiveness associated with efforts in and through government to resolve public problems" from the definition explained that the behavior that is fixed and repetitive in relation to the existing business in and through the government to solve common problems.

Every policy implemented is not all that works well and correctly. The success of policy implementation will be determined by many variables or factors, and each of these variables are interconnected with each other. [5] states that there are several theories developed on Policy Implementation, namely; George C. Edward III, Merilee S. Grindle, Daniel A. Mazmanian and Paul A. Sabatier, van Meter and van Horn, Cheema and Rondinelli, and David L. Weimer and Aidan R. Vining.

\section{1) Theory of George C. Edwards III}

In reviewing the implementation of public policy, Edward III began by asking two questions, namely: a) what is the precondition for successful policy implementation? b) What are the main obstacles to successful policy implementation?
George C. Edward III tried to answer these two questions by examining four factors or variables of policy, namely: (1) Communication, (2) Resources, (3) Disposition, and (4) Bureaucratic. The four variables also relate to each other.

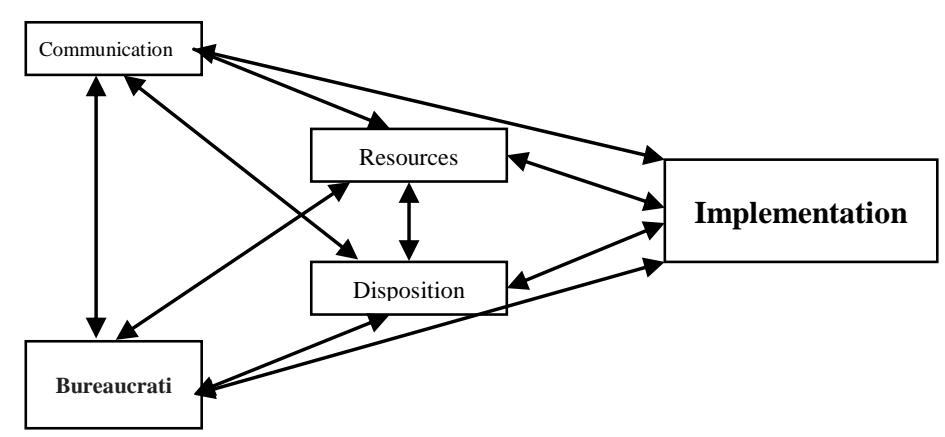

Fig 1. Approach to Implication Problems according to Edward III

\section{2) Merille S. Grindle's Theory}

The successful implementation according to Merilee S. Grindle is influenced by two main variables, namely the contents of the policy and the implementation environment.

Content variables of this policy include: (1) the extent to which the interests of the target group or target group are contained in the contents of the policy, (2) the types of benefits received by the target group, (3) the desired level of change from a policy, (4) what is the location appropriate program, (5) whether the policy has specified the implementer, (6) whether a program is supported by adequate resources.

While policy environment variables include: (1) how much strength, interest, and strategy possessed by the actors involved in policy implementation, (2) characteristics of the ruling institutions and regimes, (3) the level of compliance and response of the target group.

\section{3) Theories of Daniel A. Mazmanian and Paul A. Sabatier}

According to Mazmanian and Sabatier, there are three groups of variables that influence the success of implementation, namely: (1) the characteristics of the problem (tractability of the problems) (2) characteristics of the policy / law (3) environmental variables.

According to Meter and Horn, there are five variables that affect implementation performance, namely; (1) Standards and means of policy; (2) Resources; (3) Communication between organizations and strengthening activities; (4) Characteristics of the implementing agent; (5) Social, economic and political conditions.

\section{4) Theory of G. Shabbir Cheema and Dennis A. Rondinelli}

G. Shabbir Cheema and Dennis A. Rondinelli state that there are four factors that influence the implementation of decentralized public policy. These four factors are: 
environmental conditions, relationships between organizations, organizational resources for program implementation, characteristics and capabilities of implementing agencies. And this theory can be seen as this follow figure.

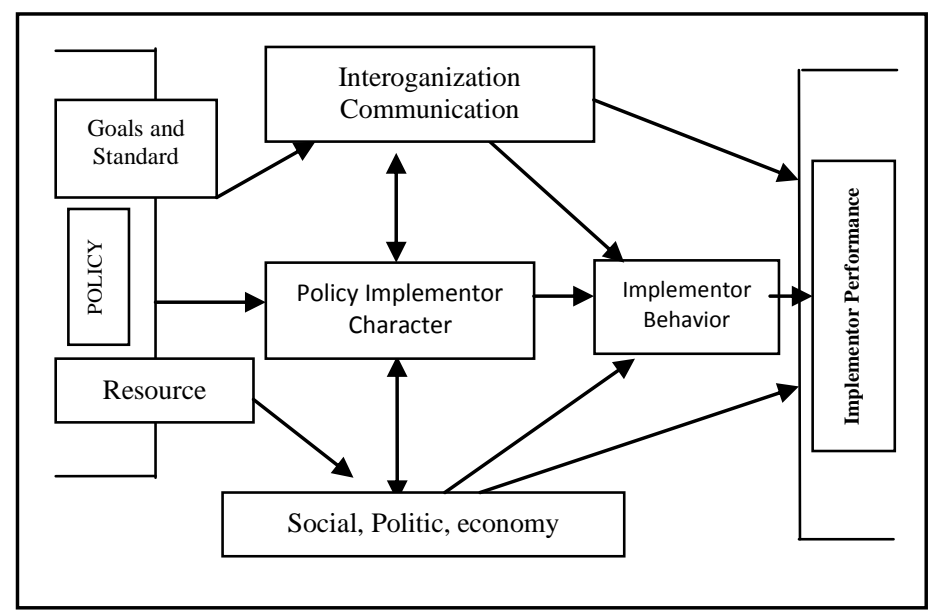

Fig. 2. Implemetation Process

\section{5) Theory of David L. Weimer and Aidan R. Vining}

In Weimer and Vining's view there are three groups of large variables that can affect the success of a program's implementation, namely: (a) policy logic (b) the environment in which the policy is operated; and (c) the ability to implement policies.

\section{B. Primary School Accreditation}

School accreditation is an assessment activity carried out by the government and / or an independent institution authorized to determine the appropriateness of education programs and / or units on formal and non-formal education pathways at all levels and types of education, based on criteria, as a form of public accountability carried out in an objective, fair, transparent and comprehensive manner using instruments and criteria that refer to National Standards.

\section{Objectives and Benefits of School Accreditation}

The purpose of holding school / madrasah accreditation activities are: first, providing information about the feasibility of schools / madrasas or programs implemented based on National Education Standards. second provides recognition of feasibility ratings, third providing recommendations regarding quality assurance for education for programs and or accredited education units and related parties. And the forth geting an overview of the state of madrasah performance and to determine the level of feasibility of a madrasa in carrying out education. The last is as a basis that can be used as a tool for guidance and development in order to improve the quality of education in madrasas.

\section{METHODOLOGY}

The method used in this study is a qualitative research method that is doing research in the context of such needs (natural) based on empirical facts without change and intervention by researchers [6].

The source of this research data is the Head of the District Education and Culture Office of Medan Regency, School Accreditation Implementing Team, School Principal, and school staff from several elementary schools in Medan Area Subdistrict. Data collection technique are interview, documentation, and observation.

The analysis process are: data reduction, data display, and conclusion drawing/verification Test credibility is done by triangulation.

\section{RESULTS AND DISCUSSION}

\section{A. Implementation of Accreditation Policies at the Medan Area Public Elementary School}

In this study, the approach used in analyzing the implementation of School / Madrasah Accreditation Policies in State Primary Schools in Medan Area is a theory put forward by George C. Edwards. In Edwards III's view there are four factors that influence public policy, namely communication, resources, disposition and bureaucratic structure. The influence of these four factors in the implementation of school/madrasah accreditation policies is as follows:

\section{1) Communication}

This aspect of communication is in the form of accreditation policy decisions, implementation instructions, orders and others. External communication occurs between KPA-S/M and accreditation target schools.

External communication occurs between KPA-S/M and accreditation target schools. In this communication the aim is that they know the procedures, standard operating procedures, real field conditions, what must be prepared and implemented for the purpose of implementing the school accreditation policy can be achieved and realized.

So it can be concluded that the communication process that occurs in the implementation of school accreditation policies is meeting oriented, to delivery of clear information, and to minimize the difference in the ability of the policy implementer.

\section{2) Human Resources (HR)}

Resources are chosen as factors that influence the success of policy implementation because policy implementation requires the support of human resources and budget/financial resources. 
The human resources that resposible to implementate this policy consit of:

- National-School/Madrasah Accreditation Board (BAN-S/M); formulate operational policies, disseminate policies and implement $\mathrm{S} / \mathrm{M}$ accreditation.

- Provincial-School/Madrasah Accreditation Board (BAP-S / M); carry out accreditation for Kiden Garden Education, Elementary/Madrasah, Junior School, Senior School.

- Accreditation Implementing Unit (UPARegency/City; help BAP-S/M carry out accreditation.

From the results of the study showed that the human resources tasked with carrying out the implementation of school accreditation, especially public elementary schools in Medan Area are:

- Accreditation that implements human resources or KPA-S / M consists of people, namely 1 coordinator and 4 members.

- Financial resouces support by national income and budget

\section{3) Disposition}

Disposition in this study are the willingness, desire and tendency of the actors to carry out the policy seriously so that policy objectives can be realized. Indicators of disposition in implementation consist of Recruitment, Discipline, Performance and Incentives.

- Recruitment of executors of open and integrated school accreditation involving parties who are experienced in the field of accreditation implementation,

- Discipline of implementing school accreditation is an alarming part, the implementation time from the socialization schedule to the issuance of accreditation certificates is an important part of the implementation of the accreditation policy at the Medan State Elementary School.

- The performance of the school accreditation executor in carrying out his duties and responsibilities is an important part of the implementation process of the accreditation policy at the State Elementary School Medan Area. Tidiness in working, and understanding of the entire series of stages of accreditation implementation in accordance with the applicable SOPs reflects good forms of performance.

- Incentives provided to school accreditation implementers, namely Income Increase Allowances (TPP) and Allowances for Technical Executive Activities (PPTK).

\section{4) Bureaucratic}

The bureaucratic structure includes dimensions of fragmentation, namely the dissemination of responsibility for a policy to several different bodies that require coordination. In addition, the bureaucratic structure includes standard dimensions of operational procedures that will facilitate and equate the actions of policy implementers in carrying out their duties.

Support for the implementation of state primary school accreditation policies in Medan District Areas that already have clear and measurable work Procedure Operational Standard (POS). State Primary Schools in Medan Regency in implementing school accreditation follow work procedures and use accreditation POS as a reference. While the form of fragmentation of the implementation of accreditation as a form of bureaucratic support is shown in Fig 3 .

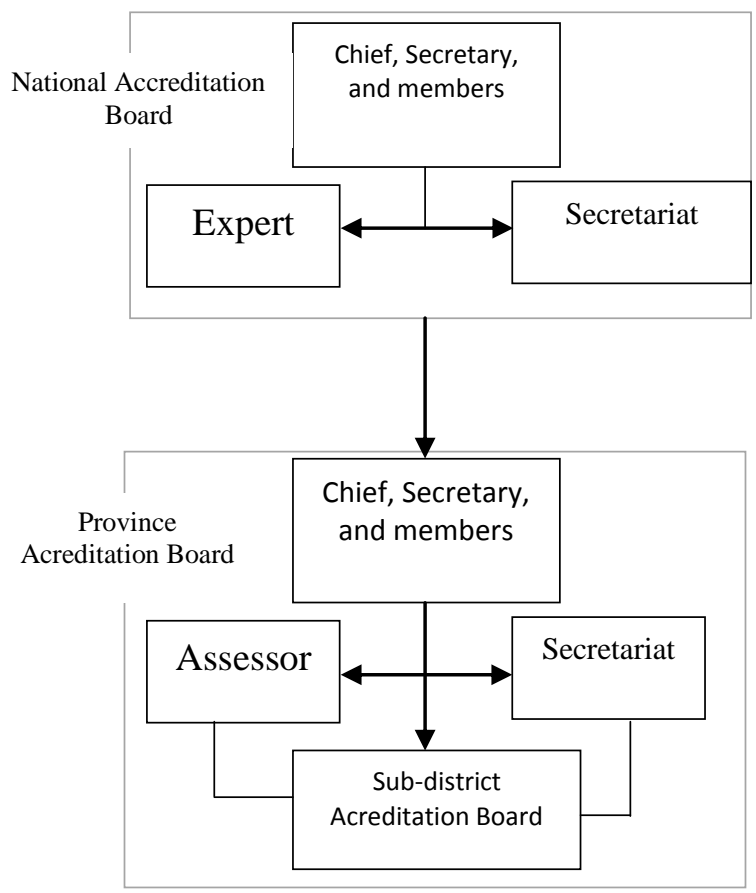

Fig 3. Organisation Sturucture of BAN-SM

\section{CONCLUSION}

Based on the results of the data analysis that has been presented, the overall results of this study can be summarized that implementation of the policy of the implementation of State Primary School accreditation in the Medan Region consists of using the theoretical study proposed by George C. Edwards. Where research can answer research objectives, namely: first, the communication process that occurs in the implementation of school accreditation policies in Stated Elementary School is meeting oriented. Second, The human resources of Acreditation Implementation consists of 1 coordinator and 4 members and financial resouces support by national income and budget. Third, ddisposition form in this study are Recruitment, Discipline, Performance and Incentives. and the form of bureaucratic support for the implementation of the accreditation policy is the existence of fragmentation that has a clear organizational structure and division of tasks for each work unit. 


\section{REFERENCES}

[1] Colquitt, Jason A., Jeffery A. LePine \& Michael J. Wesson. Organizational Behavior, Improving Performance and Commitment in the Workplace", New York : McGraw Hill., 2009, pp. 311-314

[2] William N. "Public Policy Analisys," Yogyakarta: Hanindita. 2002, pp. 18-22.

[3] Bungin, B, Qualitative Metodology Reserch," Jakarta: Kencana. , 3rd ed., 2010. pp. 17-16

[4] Danim, S. Pengantar Studi Penelitian Kebijakan. Jakarta: Bumi Aksara. 2000, pp. 89
[5] Badan Akreditasi Nasional Sekolah/Madrasah. 2010. Laporan Capaian Kinerja BAN S/M Tahun 20072011, Balitbang, Kemdiknas, Jakarta, Unpublish

[6] Arikunto S, Prosedur Penelitian: Suatu Pendekatan Praktis. Jakarta: Rineka Cipta. 2002, pp. 121-122 